TECTONICS, VOL. 5, No. 7, PAGES 995-1006, DECEMBER 1986

\title{
THERMOCHRONOLOGIC EVIDENCE OF MAJOR TECTONIC DENUDATION ASSOCIATED WITH DETACHMENT FAULTING, NORTHERN RUBY MOUNTAINS - EAST HUMBOLDT RANGE, NEVADA
}

\author{
Roy K. Dokka and Michael J. Mahaffie ${ }^{1}$ \\ Department of Geology and Geophysics, \\ Louisiana State University, Baton Rouge
}

Arthur W. Snoke

Department of Geology and Geophysics, University of Wyoming, Laramie

\begin{abstract}
Fission track (FT) thermochronology studies on igneous and metamorphic rocks from the Ruby Mountains- East Humboldt Range metamorphic core complex provide important constraints on the timing and nature of major midTertiary extension in northeast Nevada. Rocks from within the Ruby-East Humboldt detachment (brittleductile normal-sense shear) zone were analyzed; the dominant lithology studied was variably mylonitic mafic orthogneiss. Nonmylonitic amphibolite from the top of the structurally lower migmatitic core and porphyritic biotite granodiorite from the Oligocene (circa $36 \mathrm{Ma}$ ) Harrison Pass pluton were also studied. FT ages on apatite, zircon, and sphene (except one 18.4-Ma apatite from the basal portion of the detachment zone) are concordant and range in age from 26.5 Ma to 23.6 Ma; all ages overlap at $1 \sigma$ between $25.4 \mathrm{Ma}$ and $23.4 \mathrm{Ma}$. These data suggest that rocks of the upper and middle portions of the detachment zone cooled rapidly from temperatures above $\sim 285^{\circ} \mathrm{C}$ (sphene closure temperature) to below $\sim 70^{\circ} \mathrm{C}$ (lower temperature limit of track stability in apatite) near the beginning of the Miocene (minimum cooling rate of $40^{\circ} \mathrm{C} / \mathrm{Ma}$ ). The length distribution of confined fission tracks in apatites from these exhumed middle crustal rocks is
\end{abstract}

\footnotetext{
1 Presently at Shell Western Exploration and Production, Inc., Houston, TX 77001

Copyright 1986

by the American Geophysical Union.

Paper number 6T0445.

0278-7407/86/006T-0445\$10.00
}

strikingly similar to those of rocks known to have cooled rapidly (Fish Canyon ash flow tuff). The lower part of the detachment zone as well as the underlying migmatitic core also cooled through sphene and zircon closure temperatures during this time interval, but apparently only cooled to a temperature within the zone of partial annealing of apatite $\left(\sim 70^{\circ}-130^{\circ} \mathrm{C}\right)$. Residence of these rocks in this zone led to a partial retention of fission tracks, thus resulting in a reduced age. Confined track length distributions from apatite provide independent evidence of very rapid cooling but also indicate that the rocks of the lower detachment zone experienced a more protracted cooling history (remained hotter longer) than structurally higher levels of the zone. FT data firmly establish the lower limit on the timing of mylonitization during detachment faulting in this area as $23.4 \mathrm{Ma}$. Rapid cooling of the region is considered to reflect large-scale tectonic denudation (intracrustal thinning), the vertical complement to crustal extension. Rocks originating in the middle crust $(10-15 \mathrm{~km})$ were quickly brought near the surface along the Ruby- East Humboldt detachment fault (brittle-ductile simple shear zone) and juxtaposed against brittlely extended rocks deformed under upper crustal conditions.

\section{INTRODUCTION}

Major advances have been made during the past 20 years in improving our understanding of the processes involved in the rifting of continents. Perhaps the most exciting of these recent developments has been the recognition of the important role played by low-angle normal faults (detachment faults) in extensional orogenesis. For 
example, field geologists, followed by reflection seismologists, have demonstrated that the most highly extended portions of the Basin and Range province of the western United States were the sites of major mid- to late-Tertiary detachment faulting [e.g., Longwell, 1945; Anderson, 1971; McDonald, 1976; Davis and Coney, 1979; Wernicke, 1981; Armstrong, 1982; Allmendinger et al., 1983].

Determining the timing of deformation of all of the affected structural levels is one of the most difficult problems associated with detachment fault complexes. Although the hanging wall (upper plate) of the detachment is likely to contain extensionrelated time markers (syntectonic sedimentary sequences), the footwall generally offers few opportunities to resolve the timing of its deformational history. In this study of the Ruby Mountains-East Humboldt Range metamorphic core complex, we have approached this problem using new fission track (FT) data in conjunction with published $40 \mathrm{Ar}-39^{\circ} \mathrm{Ar}$ thermochronologic data to determine the cooling history of the igneousmetamorphic complex that forms the footwall. Because changes in the thermal history (shown as inflection points on time-temperature curves) of an orogen are likely to be a reflection of tectonic events, we assert that these data can shed light on the problems of the chronology of tectonic events (e.g., timing of mylonitization and the age of movement along the Ruby-East Humboldt detachment).

FT thermochronology offers several advantages over other isotopic dating methods that makes it ideal for tectonic studies: (1) Temperature is the only environmental factor that affects the retentivity of fission tracks in minerals [Fleischer et al., 1975]; this is in marked contrast with, for example, K-Ar systems which can be disrupted by several environmental factors (e.g., pressure, weathering, tectonic stress) as well as mass transfer, (2) By virtue of the low temperature of stability of fission tracks in common minerals (e.g., apatite can yield information in the range of $70^{\circ}-130^{\circ} \mathrm{C}$ ), one can more closely relate subtle tectonically induced changes in the cooling history of an orogen with changes in paleosurface processes such as erosion and sedimentation.

\section{GEOLOGIC FRAMEWORK}

A complex history of mid-Mesozoic compressional tectonics, associated plutonism and metamorphism, and superimposed mid-Tertiary extensional orogenesis is recorded in the rocks of the northern Ruby Mountains and East Humboldt Range of northeastern Nevada (Figure 1a). Geologic relations of the region have been summarized by Howard et al. [1979], Howard [1980], Snoke [1980], Kistler et al. [1981], Snoke and Lush
[1984], and Snoke and Howard [1984]. Figure 1b is a geologic map of the area.

Rocks of the area can be grouped into four major litho-tectonic sequences that include the following: (1) a homocline of non-metamorphosed and greenschist grade Paleozoic strata (located south of the Oligocene Harrison Pass pluton; Figure 1b); (2) an upper amphibolite facies migmatitic complex of recumbently folded metamorphosed late Proterozoic and Paleozoic miogeoclinal strata (metacarbonate, quartzite, and schist) that is intimately intruded by gneissic, peraluminous granitoid rocks, and other plutonic rocks (located north of the Harrison Pass pluton); the occurrence of sillimanite plus or minus kyanite in the northern part of the East Humboldt Range indicates that temperatures of at least $550^{\circ}$. $600^{\circ} \mathrm{C}$ and pressures of $4.5-6.0 \mathrm{kbars}$ were attained at the peak of regional metamorphism (similar conditions probably prevailed in the northern Ruby Mountains and the southern East Humboldt Range [Snoke and Lush, 1984]); (3) an overlying highly attenuated mylonitic shear zone formed of the same rocks as the migmatitic complex; (4) structurally higher fault- bounded slices (extensional allochthons) of late Paleozoic to Early Triassic rocks and Tertiary sedimentary and volcanic rocks; these rocks occur in the hanging walls of low-angle normal faults of late Oligocene to early Miocene (Ruby-East Humboldt detachment and associated unnamed faults). The mid-Tertiary extensional event was particularly important in that it resulted in the juxtaposition of unmetamorphosed and brittlely extended upper crustal rocks against mylonitic and regionally metamorphosed rocks of the middle crust $(8-13 \mathrm{~km}$ [Kistler et al., 1981] and 10-15 km [Snoke and Lush, 1984]). Lister and Snoke [1984] studied the rocks of the mylonitic zone and concluded that they formed in a zone of noncoaxial laminar flow (i.e., a ductile shear zone). Snoke and Lush [1984] proposed that extension, mylonitization, and juxtaposition of disparate structural levels was accomplished along an evolving crustal scale normal-sense brittle-ductile shear zone (detachment fault) such as that proposed by Wernicke [1981, 1985].

Several workers [Willden et al., 1967; Kistler and Willden, 1969; Kistler and O'Neil, 1975; and Kistler et al., 1981] have presented $\mathrm{K}-\mathrm{Ar}$ and $\mathrm{Rb} / \mathrm{Sr}$ isochron ages on rocks throughout the Ruby Mountains and recognized the relatively recent and pronounced cooling of the igneous-metamorphic complex. Kistler et al. [1981] present a contour map of $\mathrm{K}$-Ar biotite ages (their Figure 1) which suggests an east to west decrease in age from $\sim 36 \mathrm{Ma}$ on the eastern flank to less than $20 \mathrm{Ma}$ along the western side of the range. They interpret this pattern as reflecting the development of a regional, northeasttrending arch that formed in association with the 


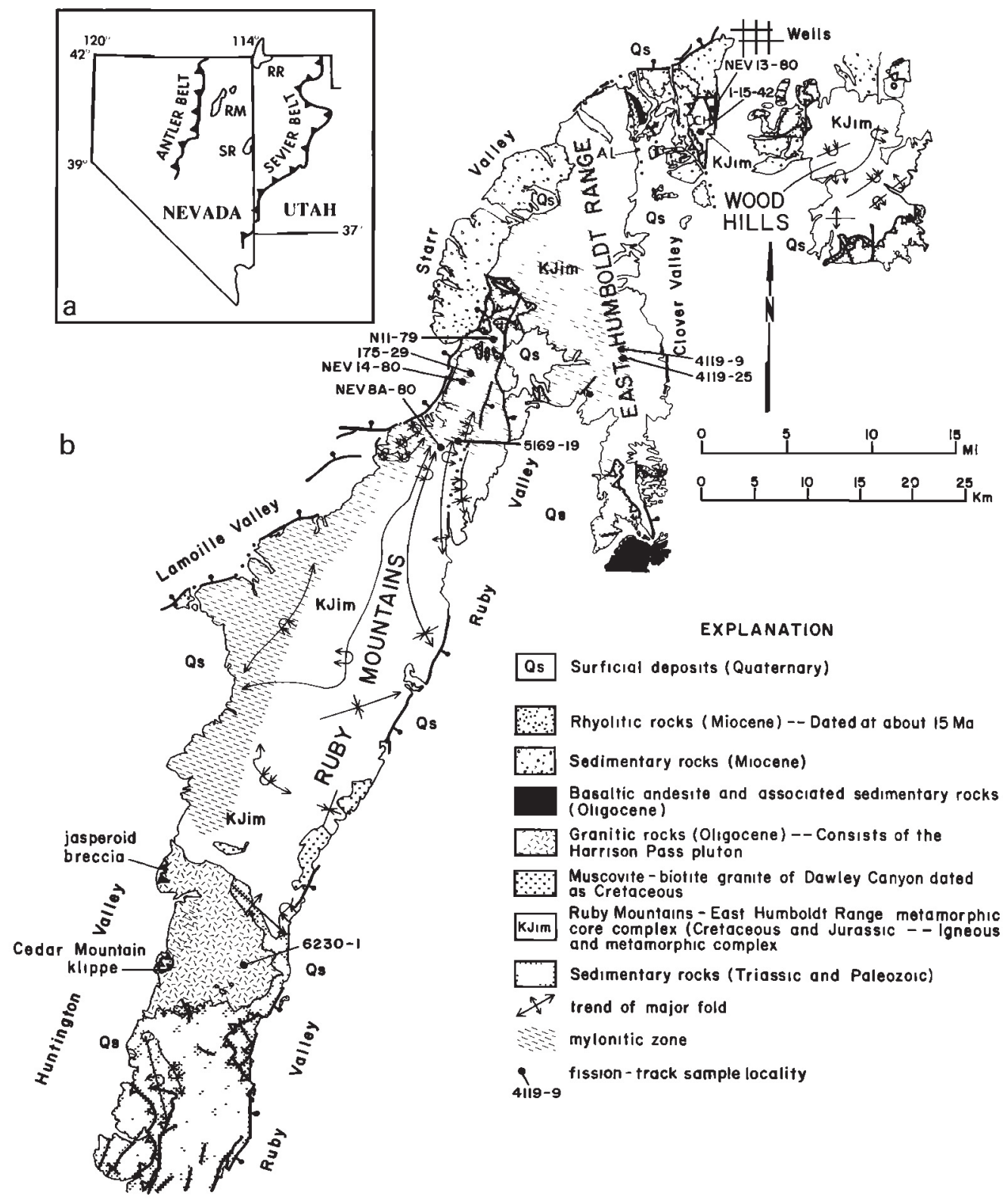

Fig. 1. (a) Map showing location of Ruby Mountains-East Humboldt Range (RM) and other Cordilleran metamorphic core complexes: SR, Snake Range; RR, Raft River-Grouse CreekAlbion Ranges. (b) Generalized geologic and fission track sample locality map of the northern Ruby Mountains-East Humboldt Range (modified from Snoke and Lush [1984]).

emplacement of the Harrison Pass pluton (circa 36 $\mathrm{Ma}$ ). They further postulate that erosion associated with arching led to the exposure of middle crustal levels $(\sim 8-13 \mathrm{~km})$ within the igneous-metamorphic complex. They argue that the deepest crustal levels are presently exposed along the west flank of the range.

Blackwell et al. [1984, 1985] studied the southern Ruby Mountains using conventional FT dating methods and claimed that apatite and sphene ages decreased systematically from $25 \mathrm{Ma}$ on the east to $13 \mathrm{Ma}$ on the west. They concurred with Kistler et al. [1981] that cooling was the result of erosion associated with the development of the normal faults (i.e., Basin-Range faults) that have blocked out the present form of the range. 
TABLE 1. Descriptive Material for Samples

\begin{tabular}{|c|c|c|c|}
\hline Field Number & Coordinates & Elevation, $\mathrm{m}$ (feet) & Structural Setting \\
\hline $6230-1$ & $\begin{array}{l}115.5096^{\circ} \mathrm{W} \\
40.3263^{\circ} \mathrm{N}\end{array}$ & $2218.9(7280)$ & undeformed part of Harrison Pass pluton \\
\hline NEV8A-80 & $\begin{array}{l}115.2939^{\circ} \mathrm{W} \\
40.7711^{\circ} \mathrm{N}\end{array}$ & $2261.6(7420)$ & $\begin{array}{l}\text { northeast corner of the Hidden Lakes uplift, } \\
\text { top of nonmylonitic migmatitic core }\end{array}$ \\
\hline $5169-19$ & $\begin{array}{l}115.2725^{\circ} \mathrm{W} \\
40.7775^{\circ} \mathrm{N}\end{array}$ & $2962.7(9720)$ & $\begin{array}{l}\text { Soldier Creek nappe; rocks variably } \\
\text { mylonitic }\end{array}$ \\
\hline $175-29$ & $\begin{array}{l}115.2656^{\circ} \mathrm{W} \\
40.8317^{\circ} \mathrm{N}\end{array}$ & $2350.0(7710)$ & $\begin{array}{l}\text { structurally below Horse Creek extensional } \\
\text { allochthon; rocks variably mylonitic }\end{array}$ \\
\hline NEV14-80 & $\begin{array}{l}115.2731^{\circ} \mathrm{W} \\
40.8256^{\circ} \mathrm{N}\end{array}$ & $2316.5(7600)$ & $\begin{array}{l}\text { structurally below Horse Creek extensional } \\
\text { allochthon; rocks variably mylonitic }\end{array}$ \\
\hline N11-79 & $\begin{array}{l}115.2397^{\circ} \mathrm{W} \\
40.8631^{\circ} \mathrm{N}\end{array}$ & $1914.1(6280)$ & $\begin{array}{l}\text { structurally below Horse Creek extensional } \\
\text { allochthon; rocks variably mylonitic }\end{array}$ \\
\hline $4119-9$ & $\begin{array}{c}115.0797^{\circ} \mathrm{W} \\
40.8419^{\circ} \mathrm{N}\end{array}$ & $2636.5(8650)$ & $\begin{array}{l}\text { Horse Creek extensional allochthon; rocks } \\
\text { variably mylonitic }\end{array}$ \\
\hline $4119-25$ & $\begin{array}{l}115.0794^{\circ} \mathrm{W} \\
40.8392^{\circ} \mathrm{N}\end{array}$ & $2641.1(8665)$ & $\begin{array}{l}\text { Horse Creek extensional allochthon; rocks } \\
\text { variably mylonitic }\end{array}$ \\
\hline NEV13-80 & $\begin{array}{l}114.9986^{\circ} \mathrm{W} \\
41.0558^{\circ} \mathrm{N}\end{array}$ & $1988.8(6525)$ & $\begin{array}{l}\text { Clover Hill dome (east side); rocks } \\
\text { variably mylonitic }\end{array}$ \\
\hline $1-15-42$ & $\begin{array}{c}115.0092^{\circ} \mathrm{W} \\
41.0450^{\circ} \mathrm{N}\end{array}$ & $2267.7(7440)$ & $\begin{array}{l}\text { Clover Hill dome (east side); rocks } \\
\text { variably mylonitic }\end{array}$ \\
\hline
\end{tabular}

Snoke et al. [1984] and Dallmeyer et al. [1986] studied the rocks beneath the Ruby-East Humboldt detachment using $\mathrm{K}-\mathrm{Ar},{ }^{40} \mathrm{Ar}-{ }^{39} \mathrm{Ar}$, and $\mathrm{Rb} / \mathrm{Sr}$ isotopic methods and propose that the igneousmetamorphic complex (originating in the middle crust) cooled rapidly during the interval $45 \mathrm{Ma}$ to 20 $\mathrm{Ma}$ in association with regional, low-angle normal faulting.

\section{ANALYTICAL METHODS}

Sample localities are shown in Figure 1b; additional descriptive material for each sample is given in Table 1. Separates of apatite, zircon, and sphene, in the size range of 62-250 um, were recovered from crushed and pulverized rock using heavy liquids and a magnetic separator. Apatite was dated using the population method whereas zircon and sphene were studied utilizing the external detector method [Naeser, 1976]. A geometry factor of 0.5 [Gleadow and Lovering, 1977] was used for the external detector method. Apatite samples were also prepared for track length measurements according to the methods outlined by Green [1981] and Laslett et al. [1982]. Lengths were measured using an optical microscope (x1500) linked via a camera leucida to a digitizing pad and microcomputer. Track length analysis provides an independent test to determine if any annealing has occurred since the apatite first began to retain fission tracks. This check for thermal disturbance serves the same purpose as an incremental heating experiment does for an ${ }^{40} \mathrm{Ar}-{ }^{39} \mathrm{Ar}$ analysis. Track length measurements also yield independent evidence regarding the cooling history of the rocks [e.g., Gleadow et al., 1983].

Thermal neutron fluence was determined using National Bureau of Standards Fission Track Glasses 962 (Cu calibration) and 963 (Cu calibration) and coupled muscovite detectors [Carpenter and Reimer, 1974]. Apatite and zircon from the Fish Canyon tuff were included as internal standards to independently measure the thermal neutron fluence of each irradiation. Statistical uncertainty for all age determinations is expressed as 1 standard deviation and was calculated according to the scheme outlined by McGee et al.[1985].

\section{RESULTS AND COOLING HISTORY RECONSTRUCTION}

Fission track age data from the northern Ruby Mountains-East Humboldt Range are presented in Table 2. Track length distributions (observed and 
TABLE 2. Fission Track Age Data

\begin{tabular}{|c|c|c|c|c|c|c|c|}
\hline $\begin{array}{l}\text { Field Number } \\
\text { (Lab Number) } \\
\text { Mineral Dated }\end{array}$ & $\begin{array}{c}\rho_{\mathrm{s}} \times 10^{6} \\
\text { tracks } / \mathrm{cm}^{2} \\
\text { (tracks counted) }\end{array}$ & $\begin{array}{c}\rho_{\mathrm{i}} \times 10^{6} \\
\text { tracks/cm² } \\
\text { (tracks counted) }\end{array}$ & $\begin{array}{c}\phi \text { Fluence } \times 10^{15} \\
\text { neutrons } / \mathrm{cm}^{2} \\
\text { (tracks counted) }\end{array}$ & $\begin{array}{l}\text { Grains } \\
\text { Counted }\end{array}$ & Method $^{a}$ & Etch b & $\mathrm{Age} \pm 1 \sigma \mathrm{Ma}$ \\
\hline $\begin{array}{c}\text { NEV-13-80 } \\
(830025)\end{array}$ & $\begin{array}{l}1.693 \\
(149)\end{array}$ & $\begin{array}{l}6.136 \\
(540)\end{array}$ & $\begin{array}{c}2.98 \\
(2000)\end{array}$ & 6 & $\mathrm{E}$ & 2 & $24.6 \pm 2.3$ \\
\hline $\begin{array}{l}\text { Sphene } \\
1-15-42 \\
(830006)\end{array}$ & $\begin{array}{l}0.208 \\
(332)\end{array}$ & $\begin{array}{l}0.509 \\
(815)\end{array}$ & $\begin{array}{c}1.09 \\
(2000)\end{array}$ & 100 & $P$ & 1 & $26.5 \pm 6.3$ \\
\hline $\begin{array}{c}\text { Apatite } \\
\text { N11-79 } \\
(830019)\end{array}$ & $\begin{array}{c}1.255 \\
(172)\end{array}$ & $\begin{array}{l}4.620 \\
(633)\end{array}$ & $\begin{array}{l}2.98 \\
(2000)\end{array}$ & 8 & E & 2 & $24.2 \pm 2.1$ \\
\hline $\begin{array}{c}\text { Sphene } \\
\text { N11-79 } \\
(830012)\end{array}$ & $\begin{array}{l}5.267 \\
(395)\end{array}$ & $\begin{array}{l}6.320 \\
(474)\end{array}$ & $\begin{array}{c}0.98 \\
(2000)\end{array}$ & 6 & $\mathrm{E}$ & 3 & $24.4 \pm 1.8$ \\
\hline $\begin{array}{l}\text { Zircon } \\
175-29 \\
(830004) \\
\text { Sphene }\end{array}$ & $\begin{array}{l}1.758 \\
(225)\end{array}$ & $\begin{array}{l}6.242 \\
(799)\end{array}$ & $\begin{array}{c}2.98 \\
(2000)\end{array}$ & 8 & $\mathrm{E}$ & 2 & $25.1 \pm 2.0$ \\
\hline $\begin{array}{l}\text { Sphene } \\
\text { NEV-14-80 } \\
\text { (830001) } \\
\text { Sphene }\end{array}$ & $\begin{array}{l}1.966 \\
(287)\end{array}$ & $\begin{array}{l}7.014 \\
(1024)\end{array}$ & $\begin{array}{c}2.98 \\
(2000)\end{array}$ & 8 & $\mathrm{E}$ & 2 & $24.9 \pm 1.8$ \\
\hline $\begin{array}{c}\text { NEV-8A-80 } \\
(830042) \\
\text { Zircon }\end{array}$ & $\begin{array}{c}10.213 \\
(623)\end{array}$ & $\begin{array}{r}11.885 \\
(725)\end{array}$ & $\begin{array}{c}0.97 \\
(2000)\end{array}$ & 6 & $\mathrm{E}$ & 3 & $24.9 \pm 1.5$ \\
\hline $\begin{array}{l}\text { NEV-8A-80 } \\
\text { (830037) } \\
\text { Sphene }\end{array}$ & $\begin{array}{l}2.458 \\
(236)\end{array}$ & $\begin{array}{l}9.260 \\
(889)\end{array}$ & $\begin{array}{c}2.98 \\
(2000)\end{array}$ & 6 & E & 2 & $23.6 \pm 1.8$ \\
\hline $\begin{array}{l}\text { spnene } \\
4119-25 \\
(830016) \\
\text { Sphene }\end{array}$ & $\begin{array}{l}1.158 \\
(117)\end{array}$ & $\begin{array}{l}4.327 \\
(437)\end{array}$ & $\begin{array}{c}2.98 \\
(2000)\end{array}$ & 7 & E & 2 & $23.8 \pm 2.5$ \\
\hline $\begin{array}{l}4119-9 \\
(830039)\end{array}$ & $\begin{array}{l}0.194 \\
(175)\end{array}$ & $\begin{array}{l}0.449 \\
(404)\end{array}$ & $\begin{array}{c}0.97 \\
(2000)\end{array}$ & 100 & $P$ & 1 & $25.1 \pm 4.2$ \\
\hline $\begin{array}{c}\text { Apatite } \\
5169-19 \\
(830045)\end{array}$ & $\begin{array}{r}0.041 \\
(56)\end{array}$ & $\begin{array}{l}0.141 \\
(176)\end{array}$ & $\begin{array}{c}0.97 \\
(2000)\end{array}$ & 100 & $\mathbf{P}$ & 1 & $18.4 \pm 2.5$ \\
\hline $\begin{array}{c}\text { Apatite } \\
5169-19 \\
(830048)\end{array}$ & $\begin{array}{l}5.721 \\
(389)\end{array}$ & $\begin{array}{l}6.588 \\
(448)\end{array}$ & $\begin{array}{c}0.97 \\
(2000)\end{array}$ & 6 & E & 3 & $25.2 \pm 1.8$ \\
\hline $\begin{array}{c}\text { Zircon } \\
6230-1 \\
(840005)\end{array}$ & $\begin{array}{l}0.217 \\
(195)\end{array}$ & $\begin{array}{l}0.519 \\
(467)\end{array}$ & $\begin{array}{c}1.00 \\
(2000)\end{array}$ & 100 & $P$ & 1 & $24.9 \pm 3.3$ \\
\hline $\begin{array}{l}\text { Apatite } \\
6230-1 \\
\text { (840003) } \\
\text { Sphene }\end{array}$ & $\begin{array}{c}1.833 \\
(176)\end{array}$ & $\begin{array}{l}6.438 \\
(618)\end{array}$ & $\begin{array}{c}2.91 \\
(2000)\end{array}$ & 6 & E & 2 & $24.7 \pm 2.2$ \\
\hline
\end{tabular}

$\lambda_{\mathrm{D}}=1.551 \times 10^{-10} \mathrm{yr}^{-1} ; \lambda_{\mathrm{F}}=7.03 \times 10^{-17} \mathrm{yr}^{-1} ;{ }^{235} \mathrm{U} / 238 \mathrm{U}=7.252 \times 10^{-3}$;

$\sigma^{238}=580.2 \times 10^{-24} \mathrm{~cm}^{2}$.

a $\mathrm{P}$ is population method; $\mathrm{E}$ is external detector method.

${ }^{b}$ Numerals indicate the following conditions: $1,30 \mathrm{~s}$ at $20^{\circ} \mathrm{C} 7 \% \mathrm{HNO}_{3} ; 2,2$ hours at $130^{\circ} \mathrm{C} 50 \mathrm{M} \mathrm{NaOH} ; 3,18$ hours at $220^{\circ} \mathrm{C} \mathrm{KOH}-\mathrm{NaOH}$ eutectic mixture. 

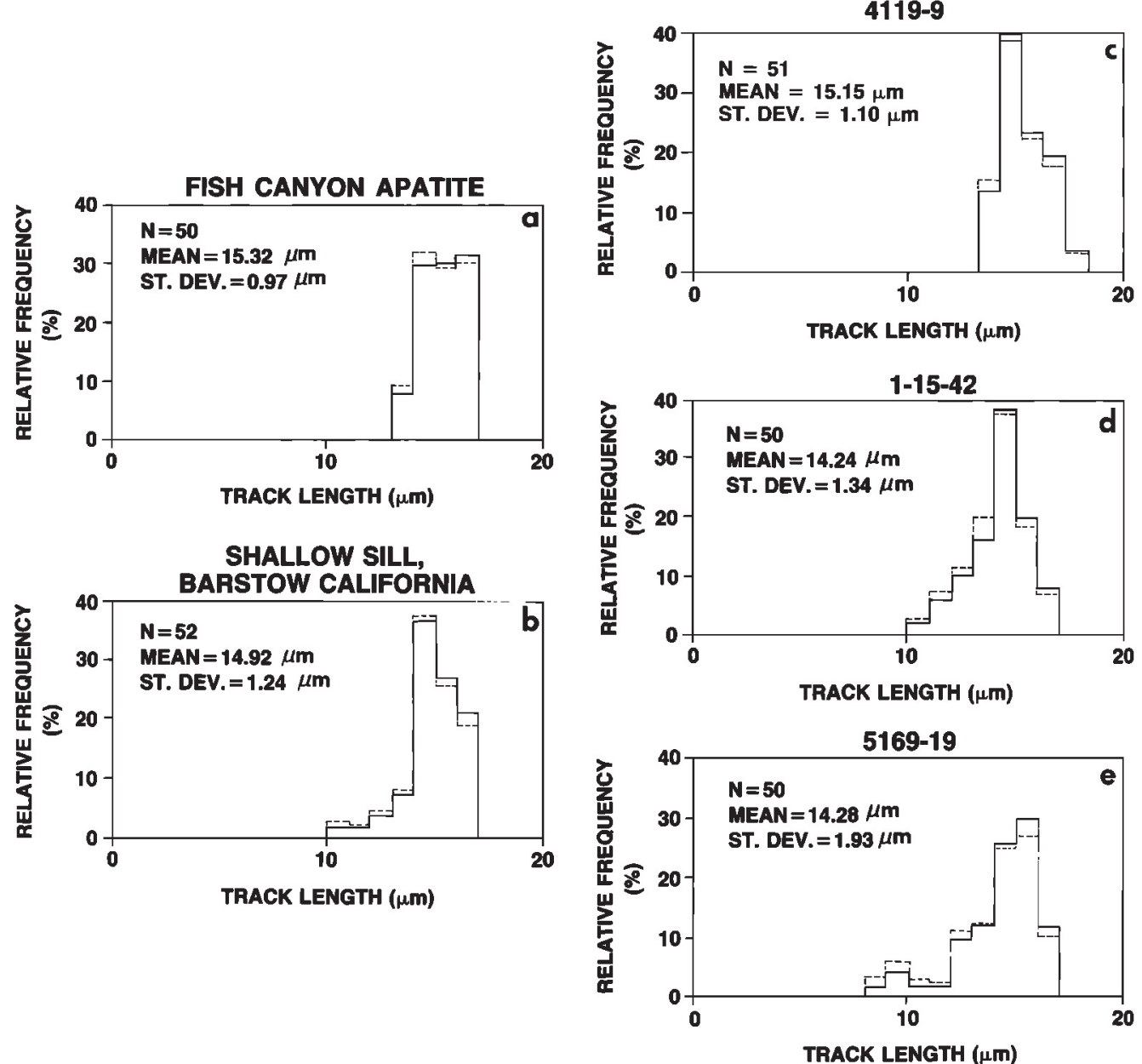

Fig. 2. Observed (solid lines) and corrected (dashed lines) confined fission track length distributions from apatites of the northern Ruby Mountains-East Humboldt Range area and selected reference materials. (a) Fish Canyon tuff, San Juan Mountains, Colorado; (b) Lead Mountain andesite sill, Barstow, California; (c) sample 4119-9, upper part of detachment zone (extensional allochthon), East Humboldt Range; (d) lower (?) part of mylonitic zone, sample 115-42, Clover Hill; (e) near the base of the mylonitic zone, 5169-19, Soldier Peak nappe.

corrected) for selected apatite samples are shown in Figure 2. We have also included a set of track length distributions from known geologica! environments (Fish Canyon tuff, Colorado, 27.8-Ma interlaboratory FT age standard and Lead Mountain shallow sill, California, 24.8-Ma) to aid the reader in evaluating our methodology and interpretation.

Sphenes, zircons, and apatites range in age from $25.1 \mathrm{Ma}$ to $23.6 \mathrm{Ma}, 25.2 \mathrm{Ma}$ to $24.4 \mathrm{Ma}$, and 26.5 Ma to $18.4 \mathrm{Ma}$, respectively. All but one sample (18.4-Ma apatite from above the base of the mylonitic zone) show overlap at $1 \sigma$ between 25.4 $\mathrm{Ma}$ and 23.4 Ma. Excluding the one discordant apatite, no significant differences can be discerned between the ages of samples, regardless of mineral species, elevation, or structural position.
To use an FT age for cooling history reconstruction, one must be able to (1) demonstrate that the system has remained closed since it began to accumulate fission tracks and (2) determine the closure temperature of the mineral system. An FT system is considered closed if it is not significantly annealed. Annealing is a temperature and time dependent process that results in track fading (i.e., the reduction in track density, the bulk property used in the calculation of an FT age [Fleischer et al., 1975; Zimmermann, 1977]) and reduction in length of individual tracks [e.g., Gleadow et al., 1983]. Fading in a sample results in a reduced age and occurs at geologically important rates in apatite over the temperature range $70^{\circ}-130^{\circ} \mathrm{C}$ (e.g., track density is stable in apatite at temperatures below $70^{\circ} \mathrm{C}$ for 

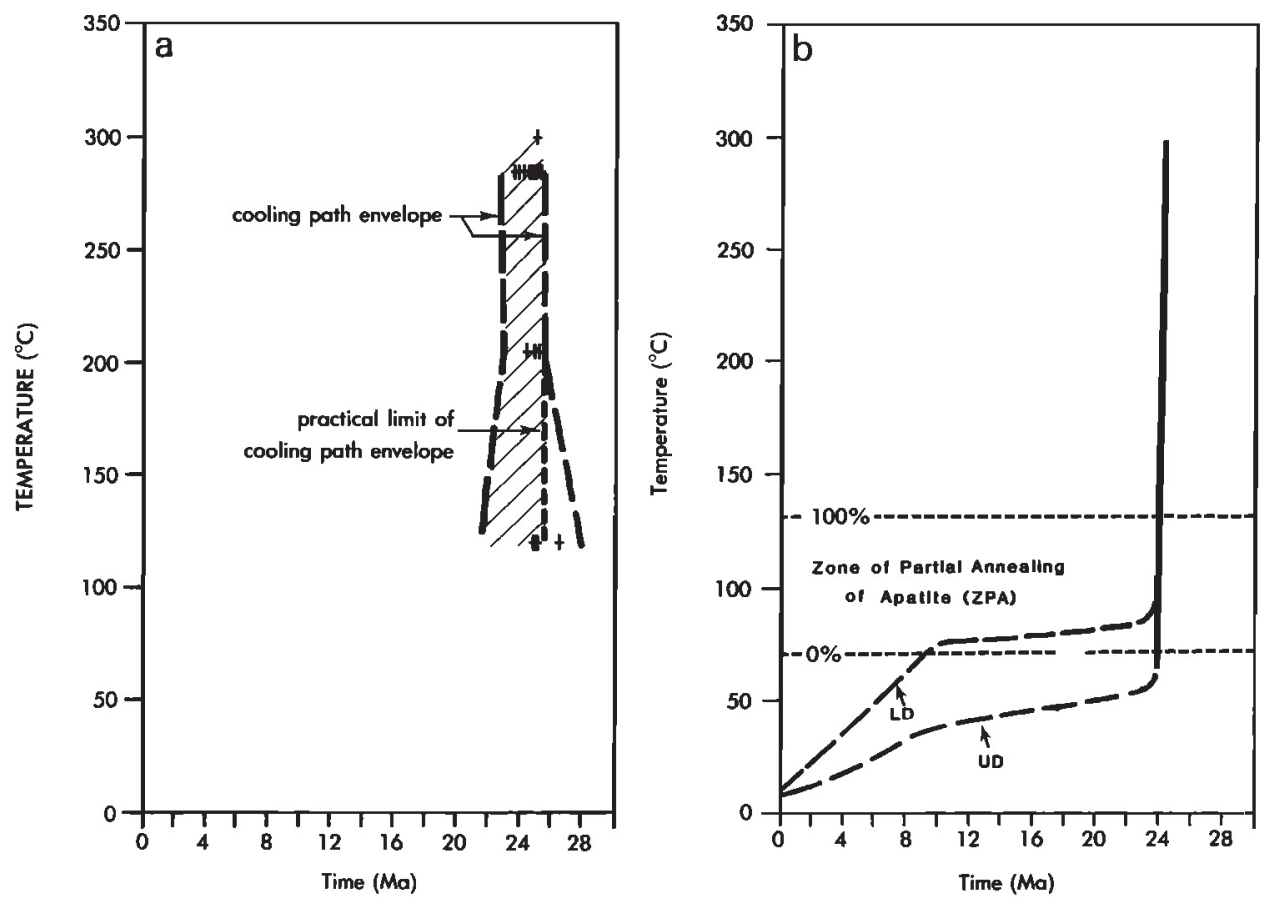

Fig. 3. (a) Cooling path envelope for rocks from within and below the Ruby-East Humboldt detachment fault. The envelope constrains the time-temperature space where cooling paths can exist. The spatial geometry of the envelope (hatched region) is based on closure temperatureapparent age relationships of FT (apatite, zircon, and sphene) and ${ }^{40} \mathrm{Ar}-{ }^{39} \mathrm{Ar}$ (biotite) thermochronometers (ages shown as crosses). An unrealistic portion of the envelope where cooling paths are negative has been deleted. (b) Possible cooling paths of upper (UD) and lower (LD) parts of the detachment zone. Inflection points in the cooling path are the result of $\sim 24-\mathrm{Ma}$ detachment faulting and $\sim 10$-Ma basin-range faulting. See text for discussion.

heating intervals of less than $200 \mathrm{Ma}$; track density in apatite shows significant fading after $\sim 10,000$ years when held at $130^{\circ} \mathrm{C}$ [Jones and Dokka, 1986]). Above $130^{\circ} \mathrm{C}$, all tracks in apatite are annealed (track density is zero); below $70^{\circ} \mathrm{C}$, the rate of fading rapidly decreases, and changes in track density are undetectable. This temperature interval where the fading rate is consequential is referred to as the zone of partial annealing (ZPA)[Naeser, 1979].

Although the closure temperature must lie within the ZPA, its location is a function of cooling rate [Dodson, 1973]. If the sample spends a significant amount of time in the ZPA then it will record an incomplete accumulation of fission tracks, and thus yield a partial (mixed) age, even though it may have cooled at a later time below its closure temperature. Age interpretation using the concept of closure temperature of FT systems is straightforward only if the sample cooled linearly through the ZPA, or cooled so rapidly that it spent a geologically insignificant amount of time in the ZPA.

Apatite ages determined on samples from the upper part of the detachment zone (extensional allochthons and upper mylonitic zone) are considered chronologically meaningful because the tracks are unannealed (Figure 2c). Ages determined on sphene and zircon can also be considered chronologically meaningful because they are concordant with those of apatite, a mineral with a lower FT closure temperature. Sphene and zircon ages from the lower part of the mylonitic zone and the underlying migmatitic complex are concordant with those from higher structural levels. In contrast, confined tracks in the 18.4-Ma apatite sample from the lower part of the mylonitic zone have been shortened by $7.2 \%$ (mean $=14.2 \mu \mathrm{m}$ ); the sample is partially annealed and its age does not record a specific event, and cannot, therefore, be interpreted in a straightforward manner.

The closure temperature of apatite was determined using the method outlined by Dodson [1973] and the track accumulation model of Zimmermann [1977]. Using a cooling rate of $40^{\circ} \mathrm{C} / \mathrm{Ma}$ (minimum value implied by concordant apatite, zircon, and sphene ages), an apatite closure temperature of $119.5^{\circ} \mathrm{C}$ was calculated. So little is known about the annealing characteristics of sphene and zircon that their closure temperatures can only be 
approximated. We have used the closure temperature values presented by Zeitler et al. [1982] in their study of the most rapidly rising (and cooling) portions of the Himalaya. They estimated that zircon and sphene have closure temperatures of $205^{\circ} \mathrm{C}$ and $\sim 285^{\circ} \mathrm{C}$, respectively.

Our cooling history reconstruction of the rocks of the igneous-metamorphic complex within and structurally below the Ruby-East Humboldt detachment zone is depicted in Figure 3 and is based on $\mathrm{FT}$ and ${ }^{40} \mathrm{Ar}-{ }^{39} \mathrm{Ar}$ biotite thermochronologic data presented by Dallmeyer et al. [1986]. In constructing this model, we have used the age (and precision estimate) and closure temperature of each thermochronometer to constrain a portion of the cooling path. It is also assumed that the rock cooled linearly between points. We have chosen to treat the cooling path as a field of time- temperature space rather than a line because it is important to account for the uncertainty of the age determinations. We refer to this time-temperature space as the cooling path envelope.

The model indicates that both the detachment zone and the migmatitic complex were cooling rapidly between circa $25.4 \mathrm{Ma}$ and circa $23.4 \mathrm{Ma}$. During this interval, rocks of the upper part of the detachment zone (extensional allochthons and the upper part of the mylonitic zone) cooled from above $\sim 300^{\circ} \mathrm{C}$ (closure temperature of biotite) to below $70^{\circ} \mathrm{C}$ (lower limit of the ZPA of apatite). These data suggest that the rate of cooling during this interval was at least $40^{\circ} \mathrm{C} / \mathrm{Ma}$. After $23 \mathrm{Ma}$, the upper part of the detachment zone cooled slowly along an undefined path (minimum integrated rate of $\sim 3^{\circ} \mathrm{C} / \mathrm{Ma}$ ) to its present temperature.

Measurements of confined track lengths in apatite provide independent evidence for a rapid cooling event. The apatite track length distribution in the sample from an extensional allochthon is similar to that in the rapidly (i.e., geologically instantaneous) cooled Fish Canyon tuff, implying that the rocks of the upper part of the detachment zone also cooled rapidly.

Concordance of biotite, sphene, and zircon ages suggests that the lower part of the detachment zone and the structurally deeper migmatitic complex shared a common cooling history with the upper detachment zone until circa $23 \mathrm{Ma}$. However, the discordant 18.4-Ma apatite age from the basal portion of the mylonite zone suggests that these rocks cooled to a temperature within the ZPA of apatite and were held there for an extended interval of time, then uplifted and cooled. (This later uplift is related to the onset of basin-range faulting and tilting of the ranges, beginning about $10 \mathrm{Ma}$ [Zoback et al., 1981].) This hypothesis for the thermal history is supported by apatite track length data. Two samples were studied, and both yield slightly negatively skewed distributions (Figures $2 \mathrm{~d}$ and 2e). Such distributions are characteristic of rocks that have cooled quickly but have spent some time in the ZPA [Gleadow et al., 1983] (note the resemblance of the apatites of the basal part of the mylonitic zone with an apatite from the rapidly cooled shallow intrusive shown in Figure 2b).

\section{DISCUSSION}

Recently, several thermochronology studies of orogenic belts have yielded concordant or nearconcordant cooling ages indicating that the crust cooled several hundred degrees centigrade during a span of a few million years [e.g., Wagner et al., 1977; Zeitler et al., 1982; Dokka, 1984; Mahaffie and Dokka, 1986]. In each case, independent geologic evidence suggested that cooling was accomplished by major erosion in association with surface uplift. The sensitivity of the FT method has been dramatically demonstrated by the work of Zeitler et al. [1982] in the Nanga Parbat region of northern Pakistan, the most rapidly rising and eroding part of the Himalaya. Their studies suggest that rocks now exposed at the surface contain zircons that were above $200^{\circ} \mathrm{C}$ as recently as $1.5 \mathrm{Ma}$.

Mid-Tertiary rapid cooling of the northern Ruby Mountains-East Humboldt Range was accompanied by neither major regional erosion nor major sedimentation in surrounding areas, as would be expected if the cooling was the result of erosion. Instead, the geologic record indicates that the landscape was disrupted into a series of local normal fault-controlled basins and ranges that were underlain and kinematically linked to the Ruby-East Humboldt detachment, a crustal scale brittle-ductile low-angle normal fault (Figure 4). These basins were filled with alluvial fan and lacustrine deposits derived from local sources [Snelson, 1957; Snoke et al., 1983; Snoke and Lush, 1984]. High relief is indicated by the localized occurrence of coarse, angular monolithologic breccias (i.e., megabreccia lenses) of Miocene age that were probably shed from evolving, fault-controlled range fronts [Snoke and Lush, 1984]. Early basinal deposits include late Oligocene-early Miocene alluvial fan deposits that were derived substantially from upper plate, unmetamorphosed, upper Paleozoic sources and to a lesser degree from eroded upper Oligocene-lower Miocene volcanic rocks [Snoke et al., 1983]. The degree of unroofing of local ranges may not have been great, judging by the lack of clasts derived from the igneous-metamorphic complex, until after $15 \mathrm{Ma}$ [Snoke and Lush, 1984]. We conclude, therefore, that erosion in association with surface uplift cannot by itself explain the rapid cooling of the region during mid-Tertiary time.

Rifting of continental lithosphere is likely to result in extended terranes characterized by abrupt structural and thermal transitions (e.g., transform faults, brittle deformational structures superimposed 


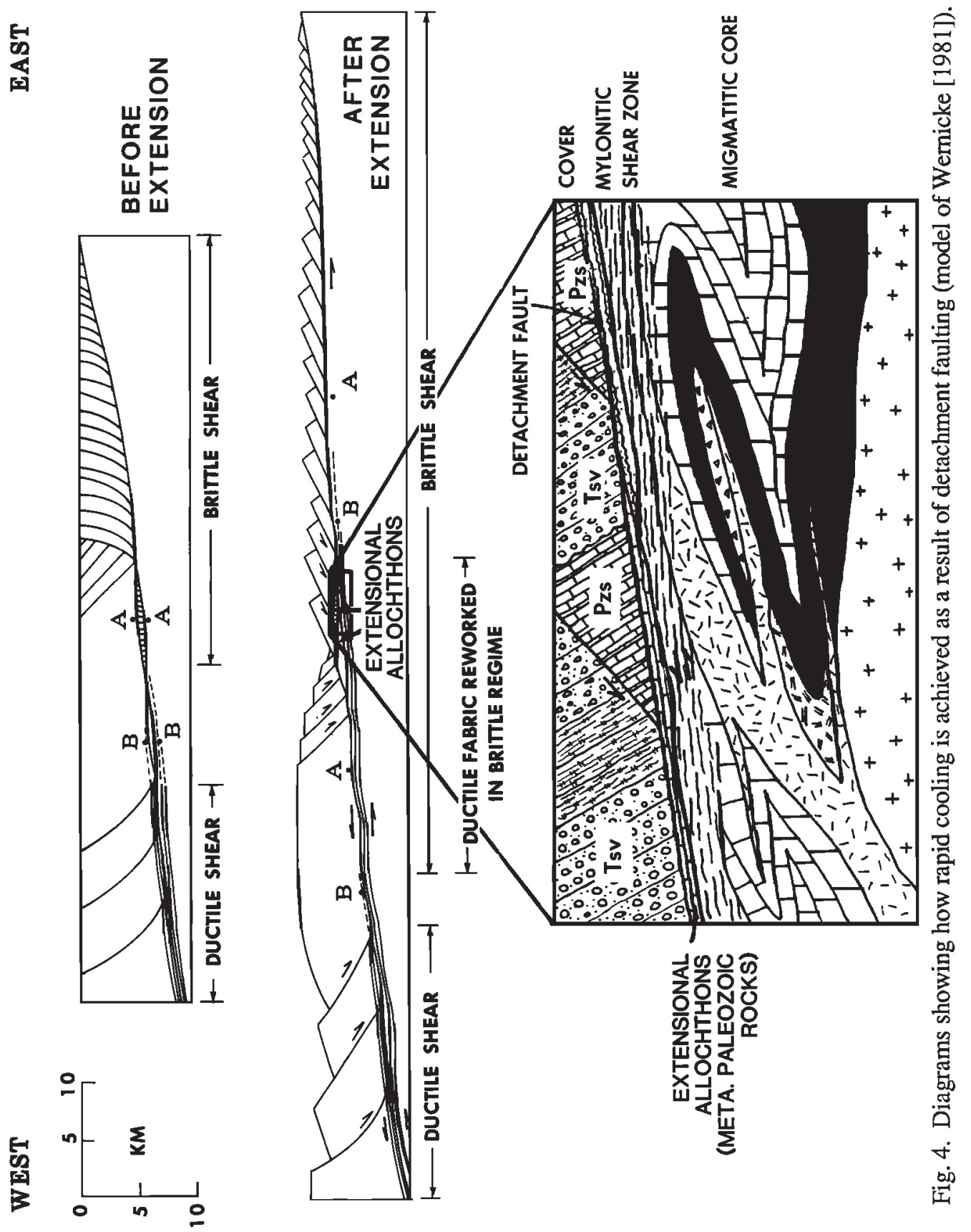


on ductile flowage features, unmetamorphosed rocks on top of amphibolite-grade rocks, and compressed fossil geothermal gradients)[Dokka and Pilger, 1983]. Those processes that result in mechanical thinning of the lithosphere during extensional orogenesis are here termed tectonic denudation (TD). Although the thermal consequences of TD are similar to those of erosion, in that deeper (warmer) crustal levels are brought nearer to the surface and cooled, TD differs markedly from erosion in terms of the location in the crust where material is removed. Cooling of deeper crustal levels by erosion occurs as material is removed at the surface, whereas tectonic denudation results in rapid cooling of lower-plate rocks as higher structural levels are progressively attenuated. In the case of the northern Ruby Mountains- East Humboldt Range, rocks of the mylonitic shear zone and migmatitic core were exhumed and cooled as the hanging wall was removed along the Ruby-East Humboldt detachment fault (Figure 4).

In summary, we consider that all of the above geochronologic, structural, and sedimentologic data are consistent with a model of large-scale tectonic denudation (intracrustal thinning) associated with crustal extension of the northern Ruby MountainsEast Humboldt Range during the late Oligocene-early Miocene. Profound cooling of middle crustal rocks occurred as higher levels were tectonically denuded by extensional processes.

\section{CONCLUSIONS}

The following conclusions were reached during this study of the northern Ruby Mountains-East Humboldt Range of northeast Nevada.

1. Fission track analysis of the igneousmetamorphic complex lying within and below the Ruby-East Humboldt detachment fault indicates that middle crustal rocks were rapidly brought near the surface and cooled during late Oligocene- early Miocene time ( $25 \mathrm{Ma}$ to $23 \mathrm{Ma}$ ).

2. Data suggest that portions of the detachment zone and the underlying rocks experienced different cooling histories. Concordance of FT ages from the upper part of the detachment zone suggests that it cooled rapidly from temperatures above $\sim 285^{\circ} \mathrm{C}$ (assumed sphene closure temperature) to below $70^{\circ} \mathrm{C}$ (assumed lower temperature limit of stabilty of fission tracks in apatite) between circa $25.4 \mathrm{Ma}$ and $23.4 \mathrm{Ma}$ ago. Measurement of confined tracks in apatite indicate that the rocks have not been heated since early Miocene time. Apatite track length distributions are similar to volcanic rocks, which lends further support to the rapid cooling hypothesis. Rocks lying above the base of the mylonitic zone as well as rocks of the structurally lower migmatitic core cooled along a similar path through biotite, sphene, and zircon closure temperatures but did not pass completely through the partial stability zone of apatite $\left(70^{\circ}-130^{\circ} \mathrm{C}\right)$. Apatite from these rocks yields track length distributions that resemble rapidly cooled shallow intrusives.

3. Rapid cooling during late Oligocene-early Miocene time occurred concurrently with mylonitization and later brittle shear along the Ruby-East Humboldt detachment fault, a crustal scale normal-sense, brittle-ductile shear zone [Snoke et al., 1984; Snoke and Lush, 1984] as well as upper plate normal faulting and block rotation [Snoke, 1980]. Cooling occurred as the crust was drastically thinned (perhaps by as much as $10 \mathrm{~km}$ ) during extensional orogenesis.

Acknowledgments. We thank A. Baksi, R. A. Donelick, S. M. Jones, D. S. Miller, and C. W. Naeser for their careful reviews of the manuscript. Dave Dallmeyer kindly provided heavy mineral separates. Partial funding was provided by the National Science Foundation (EAR-8214236 awarded to A. W. S.). Irradiation of FT samples was made possible by a grant from the Southern Region Education Board (awarded to R. K. D.).

\section{REFERENCES}

Allmendinger, R. W., J. W. Sharp, D. Von Tish, L. Serpa, L. Brown, S. Kaufman, J. Oliver, and R. B. Smith, Cenozoic and Mesozoic structure of the eastern Basin and Range from COCORP seismic reflection data, Geology, 11, 532-536, 1983.

Anderson, R. E., Thin skin distension in Tertiary rocks of southeastern Nevada, Geol. Soc. Am. Bull., 82, 43-58, 1971.

Armstrong, R. L., Cordilleran metamorphic core complexes-From Arizona to southern Canada, Annu. Rev. Earth Planet. Sci., 10, 129-154, 1982.

Blackwell, D. D., S. Kelley, and M. Reese, Fission track evidence on the Late Cenozoic deformation of the Ruby Mountains, Nevada, Geol. Soc. Am. Abstr. Programs, 16, 446, 1984.

Blackwell, D. D., N. M. Reese, and S. Kelley, Evolution of Basin and Range structure in the Ruby Mountains and vicinity, Nevada, Proceedings Volume for the Conference on Heat and Detachment in Crustal Extension on Continents and Planets, pp. 12-14, Lunar and Planetary Institute, Houston, Texas, 1985.

Carpenter, S., and G. M. Reimer, Standard reference materials: calibrated glass standards for fission track use: NBS Spec. Publ. 260-49, 16 pp, 1974.

Dallmeyer, R. D., A. W. Snoke, and E. H. McKee, The Mesozoic-Cenozoic tectonothermal evolution of the Ruby Mountains - East Humbolt Range, Nevada: A Cordilleran metamorphic core complex, Tectonics, 5, 931-954, 1986.

Davis, G. H., and P. J. Coney, Geological 
development of the Cordilleran metamorphic core complexes, Geology, 7, 120-124, 1979.

Dodson, M. H., Closure temperature in cooling geochronological and petrological systems, Contrib. Mineral. Petrol., 40, 259-274, 1973.

Dokka, R. K., Fission-track geochronologic evidence for Late Cretaceous mylonitization and early Paleocene uplift of the northeastern Peninsular Ranges, California, Geophys. Res. Lett., 11, 46-49, 1984.

Dokka, R. K., and R. H. Pilger, Jr., A nonuniform extension model for continental rifting, Geol. Soc. Am. Abstr. Programs, 15, 286, 1983.

Fleischer, R. L., P. B. Price, and R. M. Walker, Nuclear Tracks in Solids, pp. 1- 605, University of California Press, Berkeley, 1975.

Gleadow, A. J. W., and J. F. Lovering, Geometry factor for external detectors in fission track dating, Nucl. Track Detection, 1, 99-106, 1977.

Gleadow, A. J. W., I. R. Duddy, and J. F. Lovering, Fission track analysis: A new tool for the evaluation of thermal histories and hydrocarbon potential, J. Austr. Petrol. Explor. Assoc., 23, 93- 102, 1983.

Green, P. F., "Track-in-track" length measurements in annealed apatites, $\mathrm{Nucl}$. Tracks, 5, 121-128, 1981.

Howard, K. A., Metamorphic infrastructure in the northern Ruby Mountains, Nevada, in Cordilleran Metamorphic Core Complexes, Geol. Soc. Am. Mem. 153 , edited by M. D. Crittenden, P. J. Coney, and G. H. Davis, pp. 335-347, Geological Society of America, Boulder, Colo., 1980.

Howard, K. A., R. W. Kistler, A. W. Snoke, and R. Willden, Geological map of the Ruby Mountains, Nevada, Misc. Invest. Ser. I-1136, scale 1:125,000, U. S. Geol. Surv., Reston, Va., 1979.

Jones, S. M., and R. K. Dokka, Effects of time and temperature on the length distributions of fission tracks: Implications for thermal history studies of orogenic belts and basins, Geol. Soc. Am. Abstr. Programs, 18, 506, 1986.

Kistler, R. W., and R. Willden, Age of thrusting in the Ruby Mountains, Nevada, Geol. Soc. Am. Abstr. Programs, 1, 40-41, 1969.

Kistler, R. W., E. D. Ghent, and J. R. O'Neil, Petrogenesis of garnet two-mica granites in the Ruby Mountains, Nevada, J. Geophys. Res., $86,10,591-10,606,1981$.

Kistler, R. W., and J. R. O'Neil, Fossil thermal gradients in crystalline rocks of the Ruby Mountains, Nevada as indicated by radiogenic and stable isotopes, Geol. Soc. Am. Abstr. Programs, 7, 334-335, 1975.

Laslett, G. M., W. S. Kendall, A. J. W., Gleadow, and I.R. Duddy, Bias in measurement of fission track length distributions, $\mathrm{Nucl}$. Tracks, 6, 7985,1982 .
Lister, G. S., and A. W. Snoke, S-C mylonites, $J$. Struct. Geol., 6, 617-638, 1984.

Longwell, C. R., Low-angle normal faults in the Basin and Range province: EOS Trans. $A G U$, 26, 107-118, 1945.

Mahaffie, M. J., and R. K. Dokka, Thermochronologic evidence for the age and cooling history of the upper plate of the Vincent thrust, California, Geol. Soc. Am. Abstr. Programs, 18, 153, 1986.

McDonald, R. E., Tertiary tectonics and sedimentary rocks along the transition: Basin and Range province to Plateau and thrust province, Utah, in Geology of the Cordilleran Hingeline, edited by J. Gilmore, pp. 281-317, Rocky Mountain Association of Geologists, Denver, Colo., 1976.

McGee, V. E., N. Johnson, and C. W. Naeser, Simulating the fission track dating procedure, Nucl. Tracks, 10, 365- 382, 1985.

Naeser, C. W., Fission-track dating, U.S. Geol. Surv. Open File Rep., 76-190, 1- 65, 1976.

Naeser, C. W., Thermal history of sedimentary basins: Fission-track dating of subsurface rocks, in Aspects of Diagenesis, edited by P. A. Scholle and P. R. Schluger, Spec. Publ. Soc. Econ. Paleontol. and Mineral., 26, 109-112, 1979.

Snelson, S., The geology of the northern Ruby Mountains and the East Humboldt Range, Elko County, Nevada, Ph.D. dissertation, 268 pp., Univ. of Washington, Seattle, 1957.

Snoke, A. W., The transition from infrastructure to suprastructure in the northern Ruby Mountains, Nevada, in Cordilleran Metamorphic Core Complexes, Geol. Soc. Am. Mem. 153, edited by M. D. Crittenden, P. J. Coney, and G. H. Davis, pp. 287-333, Geological Society of America, Boulder, Colo., 1980.

Snoke, A.W., and K. Howard, Geology of the Ruby Mountains-East Humboldt Range, Nevada: A Cordilleran metamorphic core complex, in Western Geologic Excursions, edited by J. Lintz, Jr., pp. 260-303, Vol. 4, Mackay School of Mines, Reno, Nevada, 1984.

Snoke, A. W., and A. P. Lush, Polyphase Mesozoic-Cenozoic deformational history of the northern Ruby Mountains-East Humboldt Range, Nevada, in Western Geologic Excursions, edited by J. Lintz, Jr., pp. 232-260, Vol. 4, Mackay School of Mines, Reno, Nevada, 1984.

Snoke, A. W., R. G. McCall, and E. H. McKee, Tertiary stratigraphy and structure in the northern East Humboldt Range, Nevada--A clue to Cenozoic regional tectonic patterns, Geol. Soc. Am. Abstr. Programs, 15, 403, 1983.

Snoke, A. W., R. D. Dallmeyer, and P. D. Fullagar, Superimposed Tertiary mylonitization on a Mesozoic metamorphic terrane, Ruby MountainsEast Humboldt Range, Nevada, Geol. Soc. Am. Abstr. Programs, 16, 662, 1984.

Wagner, G. A., G. M. Reimer, and E. Jager, The 
cooling ages derived by apatite fission track, mica $\mathrm{Rb}-\mathrm{Sr}$, and $\mathrm{K}-\mathrm{Ar}$ dating: The uplift and cooling history of the Central Alps, Institute of Geology and Mineralogy, Mem. 30, 27 pp., University of Padova, Padova, Italy, 1977.

Wernicke, B., Low-angle normal faults in the Basin and Range province--Nappe tectonics in an extending orogen, Nature, 291, 645-648, 1981.

Wernicke, B., Theory of large-scale, uniform-sense normal simple shear of the continental lithosphere, Can. J. Earth Sci., 22, 108-125, 1985.

Willden, R., H. H. Thomas, and T. W. Stern, Oligocene or younger thrust faulting in the Ruby Mountains, northeastern Nevada, Geol. Soc. Am. Bull., 78, 1345-1358, 1967.

Zeitler, P. K., N. M. Johnson, C. W., Naeser, and R. A. K. Tahirkheli, Fission-track evidence for Quaternary uplift of the Nanga Parbat region, Pakistan, Nature, 298, 255-257, 1982.

Zimmermann, R. A., The interpretation of apatite fission track ages with an application to the study of uplift since the Cretaceous in eastern North
America,Ph.D. dissertation, pp. 1-146, Univ. of Pennsylvania, Philadelphia, 1-146, 1977.

Zoback, M. L., R. E. Anderson, and G. A.

Thompson, Cainozoic evolution of the state of stress and style of tectonism of the Basin and Range Province of the western United States, in Extensional tectonics associated with convergent plate boundaries, edited by F. J. Vine and A. G. Smith, pp. 407-434, Phil. Trans. R. Soc., A300, 1981.

R. K. Dokka, Department of Geology and Geophysics, Louisiana State University, Baton Rouge, LA 70803 (504)388-2975.

M. J. Mahaffie, Shell Western Exploration and Production, Inc., Houston, TX 77001.

A. W. Snoke, Department of Geology and Geophysics, University of Wyoming, Laramie, WY 82071.

(Received June 2, 1986;

revised August 4, 1986;

accepted August 5, 1986.) 